\title{
Synthesis and Structural Characterization of
} $\left[\operatorname{Ir}_{4}(\mu-\mathbf{C O})(\mathbf{C O})_{7}\left\{\mu_{4}-\eta^{3}-\mathbf{P h} 2 \mathbf{P C}(\mathbf{H}) \mathbf{C}(\mathbf{P h}) \mathbf{P C B u}{ }^{\mathrm{t}}\right\}\left(\mu-\mathbf{P P h}_{2}\right)\right]$ :

\section{Alkyne-Phosphaalkyne Coupling and Formation of a Novel}

\section{2-phosphabutadienylphosphine Ligand}

\author{
Maria Helena Araujo ${ }^{\mathrm{a}, \mathrm{b}}$, Peter B. Hitchcock ${ }^{\mathrm{b}}$,John F. Nixon*b, \\ and Maria D. Vargas* ${ }^{\mathrm{a}}$ \\ ${ }^{\mathrm{a}}$ Instituto de Química, Universidade Estadual de Campinas, C.P. 6154, \\ 13081-970 Campinas - SP, Brazil \\ ${ }^{\mathrm{b}}$ School of Chemistry, Physics and Environmental Science, University of Sussex, \\ Brighton, BN1 9QJ, UK
}

Received: August 26, 1998

A reação de $\left[\mathrm{Ir}_{4}(\mu-\mathrm{H})(\mathrm{CO})_{9}\left(\mathrm{Ph}_{2} \mathrm{PC} \equiv \mathrm{CPh}\right)\left(\mu-\mathrm{PPh}_{2}\right)\right] \mathbf{1} \mathrm{com} \mathrm{P} \equiv \mathrm{CBu}^{\mathrm{t}} \mathrm{em} \mathrm{CH}_{2} \mathrm{Cl}_{2}$ a $35^{\circ} \mathrm{C}$ por $4 \mathrm{~h}$ leva à formação do composto inédito $\left[\operatorname{Ir} 4(\mu-\mathrm{CO})(\mathrm{CO})_{7}\left\{\mu_{4}-\eta^{3}-\mathrm{Ph} 2 \mathrm{PC}(\mathrm{H}) \mathrm{C}(\mathrm{Ph}) \mathrm{PCBu}^{t}\right\}\left(\mu-\mathrm{PPh}_{2}\right)\right] \mathbf{2}$, que contem a cadeia 2 -fosfabutadienilfosfina. $\mathrm{O}$ composto 2 forma-se também quando $\left[\mathrm{Ir}_{4}(\mathrm{CO})_{10}\left(\mathrm{Ph}{ }_{2} \mathrm{PC} \equiv \mathrm{CPh}\right)\left(\mathrm{PPh}_{2} \mathrm{H}\right)\right] 3$ é aquecido na presença de $\mathrm{P} \equiv \mathrm{CBu}^{\mathrm{t}}$, em thf, a $40{ }^{\circ} \mathrm{C}$, por $48 \mathrm{~h}$. Essas duas reações também produzem pequenas quantidades de $\left[\operatorname{Ir}_{4}(\mu-\mathrm{CO})(\mathrm{CO})_{7}\left(\mu_{3}-\eta^{2}\right.\right.$ $\left.\mathrm{HCCPh})\left(\mu-\mathrm{PPh}_{2}\right)_{2}\right] \mathbf{4}$, porque as velocidades das transformações de $\mathbf{1}$ e de $\mathbf{3}$ em $\mathbf{4}$ e das reações desses compostos com $\mathrm{P} \equiv \mathrm{CBu}^{\mathrm{t}}$ são semelhantes. $\mathrm{O}$ composto $\mathbf{2}$ foi caracterizado por dados analíticos e espectroscópicos, espectrometria de massas usando fonte de $\mathrm{FAB}$ e experimentos de $\mathrm{RMN}$ de ${ }^{1} \mathrm{H}$, ${ }^{31} \mathrm{P},{ }^{13} \mathrm{C}, 2 \mathrm{D}{ }^{31} \mathrm{P}-{ }^{1} \mathrm{H}$ HETCOR, diferença de nOe e DEPT que levaram à sua formulação $\mathrm{e}$ estabeleceram que havia ocorrido o acoplamento entre o ligante $\mathrm{Ph}_{2} \mathrm{PC} \equiv \mathrm{CPh}$ e o $\mathrm{P} \equiv \mathrm{CBu}^{\mathrm{t}}$ e a migração do hidreto para o $\mathrm{C} \alpha$ do $\mathrm{Ph}_{2} \mathrm{PC} \equiv \mathrm{CPh}$. Entretanto, esses dados não permitiram decidir se a clivagem da ligação $\mathrm{P}-\mathrm{C}_{\mathrm{sp}}$ do $\mathrm{Ph}_{2} \mathrm{PC} \equiv \mathrm{CPh}$ havia ocorrido e nem definir o modo de interação da cadeia organofosforada. A estrutura molecular do composto $\mathbf{2}$, determinada por uma análise de difração de raios-X, mostrou que o cluster exibe um arranjo metálico na forma de uma borboleta e que a cadeia organofosforada, corretamente formulada por dados espectroscópicos, interage com o poliedro metálico através de quatro ligações $\sigma$.

Reaction of $\left[\mathrm{Ir}_{4}(\mu-\mathrm{H})(\mathrm{CO})_{9}\left(\mathrm{Ph}_{2} \mathrm{PC} \equiv \mathrm{CPh}\right)\left(\mu-\mathrm{PPh}_{2}\right)\right] \mathbf{1}$ with $\mathrm{P} \equiv \mathrm{CBu}^{\mathrm{t}}$ in $\mathrm{CH}_{2} \mathrm{Cl}_{2}$, at $35^{\circ} \mathrm{C}$, for $4 \mathrm{~h}$ yields the novel compound $\left[\mathrm{Ir}_{4}(\mu-\mathrm{CO})(\mathrm{CO})_{7}\left\{\mu_{4}-\eta^{3}-\mathrm{Ph}_{2} \mathrm{PC}(\mathrm{H}) \mathrm{C}(\mathrm{Ph}) \mathrm{PCBu}^{t}\right\}\left(\mu-\mathrm{PPh}_{2}\right)\right] \mathbf{2}$, which contains the 2-phosphabutadienylphosphine chain. Compound $\mathbf{2}$ is also formed upon thermolysis of $\left[\mathrm{Ir}_{4}(\mathrm{CO})_{10}\left(\mathrm{Ph}_{2} \mathrm{PC} \equiv \mathrm{CPh}\right)\left(\mathrm{PPh}_{2} \mathrm{H}\right)\right] 3$ in the presence of $\mathrm{P} \equiv \mathrm{CBu}^{\mathrm{t}}$ in thf, at $40^{\circ} \mathrm{C}$, for $48 \mathrm{~h}$. Small amounts of $\left[\mathrm{Ir}_{4}(\mu-\mathrm{CO})(\mathrm{CO})_{7}\left(\mu_{3}-\eta^{2}-\mathrm{HCCPh}\right)\left(\mu-\mathrm{PPh}_{2}\right)_{2}\right] \mathbf{4}$ are always obtained from both reactions, because of the competing rates of the transformations of $\mathbf{1}$ and $\mathbf{3}$ into $\mathbf{4}$ and of their reactions with $\mathrm{P} \equiv \mathrm{CBu}^{\mathrm{t}}$. Compound $\mathbf{2}$ was characterized by analytical and spectroscopic studies such as FAB ms, ${ }^{1} \mathrm{H},{ }^{31} \mathrm{P},{ }^{13} \mathrm{C}, 2 \mathrm{D}{ }^{31} \mathrm{P}-{ }^{1} \mathrm{H}$ HETCOR, nOe difference and DEPT NMR experiments, which led to its formulation and established the coupling between the coordinated $\mathrm{Ph}_{2} \mathrm{PC} \equiv \mathrm{CPh}$ and $\mathrm{P} \equiv \mathrm{CBu}^{t}$ and the migration of the hydride to the $\mathrm{C} \alpha$ of the $\mathrm{Ph}_{2} \mathrm{PC} \equiv \mathrm{CPh}$ ligand. However, it was impossible to establish unambiguously if cleavage of the $\mathrm{P}-\mathrm{C}_{\mathrm{sp}}$ bond of the $\mathrm{Ph}_{2} \mathrm{PC} \equiv \mathrm{CPh}$ ligand had occurred and the mode of interaction of the organophosphorus chain. An X-ray diffraction study of compound 2 established 
a butterfly arrangement of iridium atoms with the new ligand interacting with the metal framework via four $\sigma$ bonds and the $\mathrm{PPh}_{2}$ phosphorus lone pair.

Keywords: iridium cluster, phosphaalkyne, alkyne, coupling reaction

\section{Introduction}

There are relatively few examples of alkyne-alkyne coupling reactions at polynuclear carbonyl clusters ${ }^{1}$, one example being the reaction between $\left[\operatorname{Ir}_{4}(\mu-\mathrm{H})(\mathrm{CO})_{9}\right.$ $\left.\left(\mathrm{Ph}_{2} \mathrm{PC} \equiv \mathrm{CPh}\right)\left(\mu-\mathrm{PPh}_{2}\right)\right]$ and $\mathrm{HC} \equiv \mathrm{CPh}$, which led to $\left[\mathrm{Ir}_{4}(\mathrm{CO})_{7}\left(\mu_{4}-\eta^{3}-\mathrm{PhCC}(\mathrm{H}) \mathrm{CCPh}\right)\left(\mu-\mathrm{PPh}_{2}\right)_{3}\right]^{2}$. The coordination chemistry of phosphaalkynes, $\mathrm{P} \equiv \mathrm{CR}$, has been of great interest and its similarity to alkynes has been discussed previously, and various publications and reviews have been written ${ }^{3}$. Published examples of codimerization between a phosphaalkyne and an alkyne are relatively few. For example, the reaction between $\left[\mathrm{Co}_{2}\left(\mathrm{Cp}_{2}\right)\right.$ $\left.\left(\mathrm{Me}_{3} \mathrm{SiCCSiMe}_{3}\right)\right]$ and $\mathrm{P} \equiv \mathrm{CBu}^{t}$ resulted in the desired $\eta^{4}$ 1-phosphacyclobutadiene complex $\left[\mathrm{Co}(\mathrm{Cp})\left(\eta^{4}-\mathrm{PC}\left(\mathrm{Bu}^{\mathrm{t}}\right) \mathrm{C}\right.\right.$ $\left(\mathrm{SiMe}_{3}\right) \mathrm{C}\left(\left(\mathrm{SiMe}_{3}\right)\right]$ and the reaction of $\left[\mathrm{Zr}\left(\mathrm{Cp}_{2}\right)\left(\mathrm{PMe}_{3}\right)\left(\eta^{2}-\right.\right.$ $\left.\mathrm{PCBu}^{\dagger}\right)$ ] with alkynes led to the 1-phospha-3-zircona cyclopentadiene complexes ${ }^{4}$. The only published attempt to couple similar molecules on a cluster compound involved the reaction between $\left[\mathrm{Fe}_{3}(\mathrm{CO})_{9}\right.$ $\left.\mathrm{Se}\left(\mathrm{PBu}^{\mathrm{t}}\right)-\left(\mathrm{Bu}{ }^{\mathrm{t}} \mathrm{C} \equiv \mathrm{CH}\right)\right]$ and $\mathrm{P} \equiv \mathrm{CBu}^{t}$ with led to the unexpected $\quad\left[\mathrm{Fe}_{3}(\mathrm{CO})_{7} \mathrm{Se}\left(\mathrm{PBu}^{t}\right)\left(\mathrm{Bu}{ }^{t} \mathrm{C}=\mathrm{CH}\right)\left(\mu_{3}-\mathrm{P}-\mathrm{C}(=\mathrm{C}=\mathrm{O})\right.\right.$ $\left(\mathrm{Bu}^{\mathrm{t}}\right)$ ] compound ${ }^{5}$. Although a number of 2-phosphabutadienes are known ${ }^{6}$, none have previously been obtained by the alkyne-phosphaalkyne coupling route. We recently reported that $\left[\operatorname{Ir}_{4}(\mu-\mathrm{H})(\mathrm{CO})_{9}\left(\mathrm{Ph}_{2} \mathrm{PC} \equiv \mathrm{CPh}\right)\left(\mu-\mathrm{PPh}_{2}\right)\right] \quad \mathbf{1}$ containing a terminally bound diphenylphosphinoacetylene undergoes a facile rearrangement into $\left[\operatorname{Ir}_{4}(\mu-\mathrm{CO})(\mathrm{CO})_{7}\left(\mu_{3}-\eta^{2}-\mathrm{HCCPh}\right)\left(\mu-\mathrm{PPh}_{2}\right)_{2}\right] \mathbf{4}$ which was proposed to occur via $\mathrm{CO}$ loss, $\mathrm{P}-\mathrm{C}_{\mathrm{sp}}$ bond cleavage and hydride migration to the $\alpha$-carbon of the acetylide fragment ${ }^{7}$. Cluster coordinated acetylides have been shown to undergo nucleophilic attack of alkynes at the $\alpha$-carbon ${ }^{8,9}$ and, in an attempt to trap the proposed hydrido-acetylido intermediate in the transformation of $\mathbf{1}$ into $\mathbf{4}$, this reaction was carried out in the presence of $\mathrm{P} \equiv \mathrm{CBu}^{\mathrm{t}}$. We report herein the first example of a phosphaalkyne-alkyne coupling reaction in the coordination sphere of a cluster compound, and describe the synthesis and characterization of $\left[\operatorname{Ir}_{4}(\mu-\right.$ $\left.\mathrm{CO})(\mathrm{CO})_{7}\left\{\mu_{4}-\eta^{3}-\mathrm{Ph}_{2} \mathrm{PC}(\mathrm{H}) \mathrm{C}(\mathrm{Ph}) \mathrm{PCBu}^{\mathrm{t}}\right\}\left(\mu-\mathrm{PPh}_{2}\right)\right] \quad \mathbf{2}$, which contains the 2-phosphabutadienylphosphine chain. A preliminary communication of this work has appeared elsewhere ${ }^{10}$.

\section{Results and Discussion}

The reaction of the orange compound $\left[\operatorname{Ir}_{4}(\mu-\right.$ $\left.\mathrm{H})(\mathrm{CO}){ }_{9}\left(\mathrm{Ph}_{2} \mathrm{PC} \equiv \mathrm{CPh}\right)\left(\mu-\mathrm{PPh}_{2}\right)\right] \mathbf{1}$ with $\mathrm{P} \equiv \mathrm{CBu}^{\mathrm{t}}$ in $\mathrm{CH}_{2} \mathrm{Cl}_{2}$, at $35{ }^{\circ} \mathrm{C}$, for $4 \mathrm{~h}$ resulted in a dark brown solution, from which the brown compound $\left[\operatorname{Ir}_{4}(\mu-\mathrm{CO})(\mathrm{CO})_{7}\left\{\mu_{4}-\eta^{3}-\right.\right.$ $\left.\left.\mathrm{Ph}_{2} \mathrm{PC}(\mathrm{H}) \mathrm{C}(\mathrm{Ph}) \mathrm{PCBu}^{\mathrm{t}}\right\}\left(\mu-\mathrm{PPh}_{2}\right)\right] 2$ was isolated in up to $48 \%$ yield, after purification by TLC, besides unreacted 1 and small amounts of $\left[\mathrm{Ir}_{4}(\mu-\mathrm{CO})(\mathrm{CO})_{7}\left(\mu_{3}-\eta^{2}-\mathrm{HCCPh}\right)(\mu-\right.$ $\left.\mathrm{PPh}_{2}\right)_{2}$ ] 4. Formation of $\mathbf{2}$ in $10 \%$ yield was also observed when $\left[\mathrm{Ir}_{4}(\mathrm{CO})_{10}\left(\mathrm{Ph}_{2} \mathrm{PC} \equiv \mathrm{CPh}\right)\left(\mathrm{PPh}_{2} \mathrm{H}\right)\right] 3$ was heated with $\mathrm{P} \equiv \mathrm{CBu}^{\mathrm{t}}$ in thf at $40{ }^{\circ} \mathrm{C}$ for $48 \mathrm{~h}$. In both cases, heating for longer periods of time only resulted in additional formation of $\mathbf{4}$ and decomposition. Small amounts of compound $\mathbf{4}$ were unavoidably obtained, because of the competing rates of the two reactions illustrated in Scheme 1.

The reaction of $\mathbf{4}$ with $\mathrm{P} \equiv \mathrm{CBu}^{\mathrm{t}}$ was also investigated. All attempts led to an immediate color change from orange to dark brown, but in situ ${ }^{31} \mathrm{P}\left\{{ }^{1} \mathrm{H}\right\}$ NMR showed no phosphorus signals, which indicated that the reaction had occurred, but the product underwent decomposition. Similar behavior was observed when the reaction of $\mathbf{4}$ with $\mathrm{PR}_{3}$ was investigated ${ }^{11}$.

Compound 2 was formulated on the basis of analytical and spectroscopic data discussed below. The coupling reaction between the $\mathrm{Ph}_{2} \mathrm{PCCPh}$ ligand and the $\mathrm{PCBu}^{t}$ molecule, and the hydride migration to the resulting new phosphorus carbon chain were established by ${ }^{1} \mathrm{H},{ }^{31} \mathrm{P}$ and

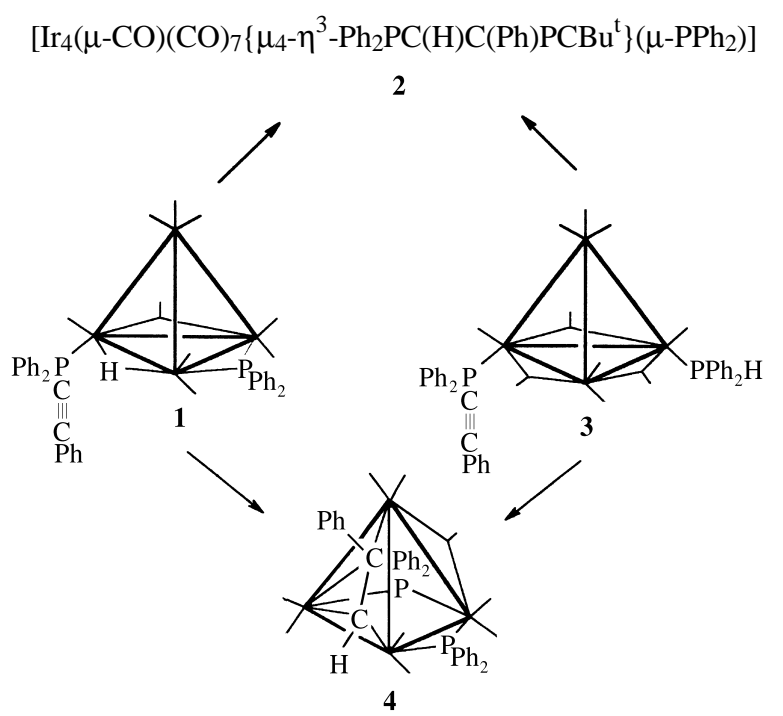

Scheme 1. 
${ }^{13} \mathrm{C}$-NMR spectroscopy. In spite of the detailed spectroscopic studies undertaken, it was impossible to establish unambiguously whether the diphenylphosphino-alkyne had undergone $\mathrm{P}-\mathrm{C}_{\mathrm{sp}}$ bond cleavage and the geometry of the metal polyhedron in $\mathbf{2}$, therefore an X-ray diffraction study had to be carried out.

\section{Solution characterization of $\left[\operatorname{Ir}_{4}(\mu-C O)(C O)_{7}\left\{\mu_{4}-\eta^{3}-\right.\right.$ $\left.\left.P h_{2} P C(H) C(P h) P C B u^{t}\right\}\left(\mu-P P h_{2}\right)\right] 2$}

The solution infrared spectrum of compound 2, between $2200-1600 \mathrm{~cm}^{-1}$, only showed absorptions due to terminal and bridging carbonyl ligands. This result suggested that the triple bond of the $\mathrm{Ph}_{2} \mathrm{PC} \equiv \mathrm{CPh}$ ligand was interacting with the metal framework, because of the absence of the $v_{\mathrm{C} \equiv \mathrm{C}}$ band at $2172 \mathrm{~cm}^{-1}$ which is observed in both starting materials $\mathbf{1}$ and $\mathbf{3}$. In the FAB mass spectrum of 2 , a molecular ion at $m / z 1568$ and sequential loss of eight $\mathrm{CO}$ ligands were observed. The mass difference between 1 and 2 clearly indicated the incorporation of one $\mathrm{PCBu}^{t}$ molecule and loss of a $\mathrm{CO}$ group, resulting in a complex having the formula "Ir $4 \mathrm{H}(\mathrm{CO})_{8}\left(\mathrm{Ph}_{2} \mathrm{PCCPh}\right)\left(\mathrm{PPh}_{2}\right)\left(\mathrm{PCBu}^{t}\right)$ ", with which the elemental analysis agreed perfectly.

The ${ }^{1} \mathrm{H}-\mathrm{NMR}$ data for $\mathbf{2}$ were consistent with the presence of both $\mathrm{PPh}_{2}$ and $\mathrm{Bu}^{t}$ groups. The absence of a hydride signal and the presence of a doublet of doublets at $\delta 5.4$ $\left(J_{\mathrm{H}-\mathrm{P}}=55\right.$ and $\left.13 \mathrm{~Hz}\right)$ suggested that the hydride ligand had migrated to one of the carbon atoms of the $\mathrm{Ph}_{2} \mathrm{PCCPh}(\mathrm{C} \alpha$ or $\mathrm{C} \beta$ ) or of the $\mathrm{PCBu}^{\mathrm{t}}(\mathrm{C} \gamma)$ ligands, because migration of the hydride to one of the phosphorus atoms would have led to a much larger one-bond H-P coupling constant, typically between 300 and $500 \mathrm{~Hz}^{12}$. A nOe difference experiment established to which of the ligands $\mathrm{Ph}_{2} \mathrm{PCCPh}$ or $\mathrm{PCBu}^{\mathrm{t}}$ the hydride had migrated. This experiment consisted of continuous irradiation of the resonance at $\delta 5.4(\mathrm{CH})$, which resulted in a nOe of some of the phenyl proton resonances, but did not affect the $\mathrm{Bu}^{\mathrm{t}}$ signal [Fig. 1a]. Likewise, when the $\mathrm{Bu}^{\mathrm{t}}$ resonance at $\delta 1.1$ was irradiated, only nOe of some of the phenyl proton resonances was observed [Fig. 1b]. Thus, the spacial proximity of the $\mathrm{CH}$ and the phenyl protons indicated that migration of the hydride had occurred either to $\mathrm{C} \alpha$ or $\mathrm{C} \beta$ of the $\mathrm{Ph}_{2} \mathrm{PCCPh}$ ligand.

The ${ }^{31} \mathrm{P}\left\{{ }^{1} \mathrm{H}\right\}$ NMR spectrum of $\mathbf{2}$ showed three sets of pseudo-triplets at $\delta 16.1,28.0$ and 116.5 with $J_{\mathrm{P}-\mathrm{P}}=5 \mathrm{~Hz}$. The $2 \mathrm{D}{ }^{1} \mathrm{H}-{ }^{31} \mathrm{P}$ shift correlation spectrum established that the lowest frequency peak could be assigned to the phosphorus atom of the $\mathrm{PCBu}^{\mathrm{t}}\left(\mathrm{P}_{\mathrm{A}}\right)$ group, and the other two resonances at higher frequency were due to the $\mathrm{PPh}_{2}$ groups $\left(\mathrm{P}_{\mathrm{B}}\right.$ and $\left.\mathrm{P}_{\mathrm{C}}\right)$ [Fig. 2]. This experiment also indicated that the strong $\mathrm{P}-\mathrm{H}$ coupling of $55 \mathrm{~Hz}$ was to the $\mathrm{P}_{\mathrm{A}}$ nucleus $(\delta$ 16.1), whilst the $13 \mathrm{~Hz} \mathrm{P}-\mathrm{H}$ coupling was to the $\mathrm{PPh}_{2}$ phosphorus $\mathrm{P}_{\mathrm{B}}(\delta 22.0)$. The signal at $\delta 116.5\left(\mathrm{P}_{\mathrm{C}}\right)$, was confidently attributed to the bridging phosphido nucleus, on the basis of previous work ${ }^{7}$. The second $\mathrm{PPh}_{2}\left(\mathrm{P}_{\mathrm{B}}\right)$ appeared at $\delta 28.0$ and it is indicative of a phosphine ${ }^{12}$, however the breaking of the $\mathrm{P}-\mathrm{C}_{\mathrm{sp}}$ bond cannot be excluded, since the $\mu-\mathrm{PPh}_{2}$ phosphorus nuclei have been shown to span a wide chemical shift range, depending on the distance between the metal atoms they bridge ${ }^{12}$.

The coupling of the diphenylphosphinoalkyne with the phosphaalkyne was strongly suggested by the ${ }^{13} \mathrm{C}\left\{{ }^{1} \mathrm{H}\right\}$ and ${ }^{13} \mathrm{C}$-NMR spectra and a DEPT experiment. These experiments made it possible to identify the $\mathrm{C} \beta\left(\mathrm{C}_{\text {quat }}\right)$ resonance as a doublet of doublets at $\delta 54.2$, with $J_{\mathrm{C}-\mathrm{P}}=37$ and $28 \mathrm{~Hz}$, and the $\mathrm{C} \alpha(\mathrm{CH})$, also as a dd, at $\delta 126.0, J_{\mathrm{C}-\mathrm{P}}=57$ and 35 $\mathrm{Hz}$, and ${ }^{1} J_{\mathrm{C}-\mathrm{H}}=164 \mathrm{~Hz}$. The chemical shifts of $\mathrm{C} \alpha$ and $\mathrm{C} \beta$ and the $\mathrm{P}-\mathrm{C}$ and $\mathrm{C}-\mathrm{H}$ coupling constants are in agreement

(b)

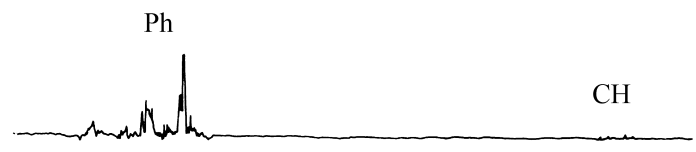

(a)

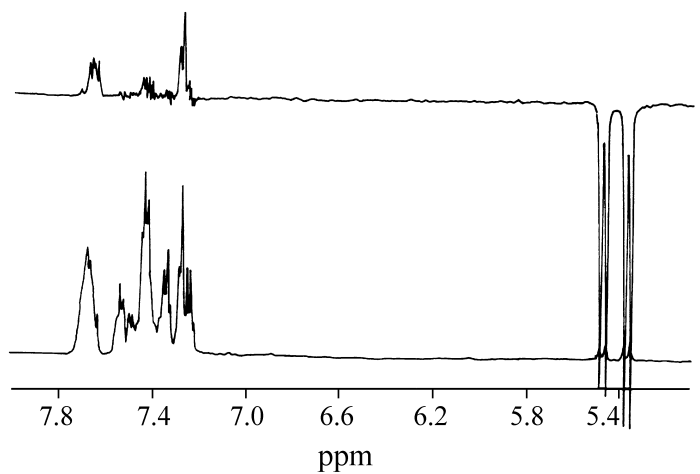

Figure 1. nOe difference spectrum of compound $\mathbf{2}$ in $\mathrm{CDCl}_{3}$ at $25{ }^{\circ} \mathrm{C}$ resulting from: (a) irradiation of the resonance at $\delta 5.4(\mathrm{CH})$ and (b) irradiation of the $\mathrm{Bu}^{\mathrm{t}}$ at $\delta$ 1.1.

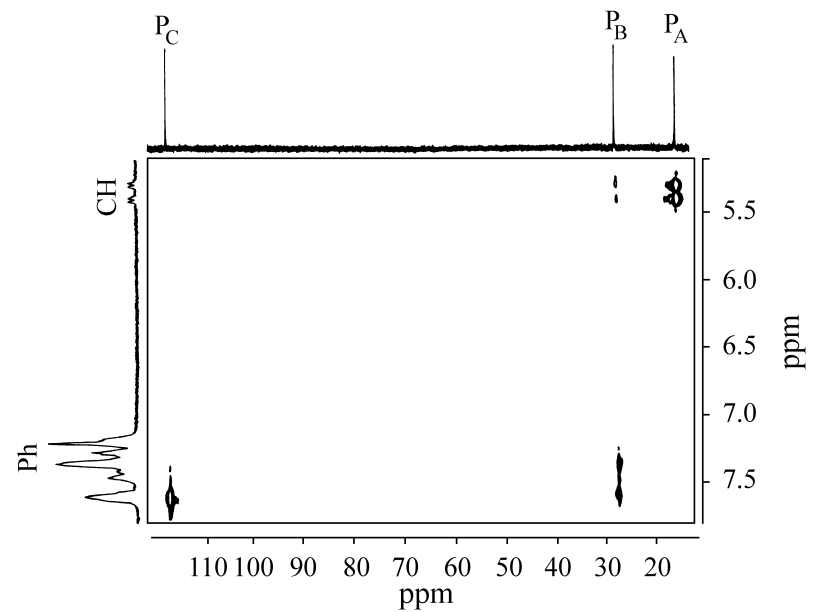

Figure 2. ${ }^{31} \mathrm{P}-{ }^{1} \mathrm{H}$ heteronuclear correlation spectrum of compound $\mathbf{2}$ in $\mathrm{CDCl}_{3}$ at $25^{\circ} \mathrm{C}$. 
with those normally observed for $\mathrm{sp}^{2}$ hybridized carbon atoms which are coordinated to organometallic compounds ${ }^{13}$. In the ${ }^{13} \mathrm{C}\left\{{ }^{1} \mathrm{H}\right\}$ NMR spectrum of 2 it was possible to identify all eight $\mathrm{CO}$ groups and to assign the bridging CO resonance at $\delta 191.2$, which is shifted to high frequency, in comparison with the terminal CO groups ${ }^{14}$. This result was in agreement with the IR and mass spectra data and the elemental analysis. It was also possible to identify five quaternary carbons and the $\mathrm{CH}$ carbon atom of the phenyl groups, in the aromatic carbon region between $\delta 141.7$ and 128.3. The two $\mathrm{C}_{\text {quat }}$ resonances at $\delta 38.5$ and 29.6, were assigned to $\mathrm{C} \gamma$ and $\mathrm{C} *$ or vice versa.

On the basis of these results two possible structures $\mathbf{A}$ and $\mathbf{B}$ were proposed for the new 2-phosphabutadienyl chain, as shown in Scheme 2. In $\mathbf{A}$ the coupling between $\mathrm{Ph}_{2} \mathrm{PCCPh}$ and $\mathrm{PCBu}^{t}$ would have occurred without cleavage of the $\mathrm{Ph}_{2} \mathrm{P}-\mathrm{C}$ bond, and in $\mathbf{B}$ cleavage would have occurred, leading to a $\mu-\mathrm{PPh}_{2}$ coordinated fragment. The trans- $\mathrm{H}$ to phospha-alkene $\mathrm{P}_{\mathrm{A}}$ arrangement would result in the large ${ }^{3} J_{\mathrm{H}-\mathrm{P}}=55 \mathrm{~Hz}$ observed.

The mode of interaction of the proposed 2-phosphabutadienyl fragments A or B to the $\mathrm{Ir}_{4}$ metal frame could only be speculated upon based on the above analytical and spectroscopic data. Because the ${ }^{13} \mathrm{C}\left\{{ }^{1} \mathrm{H}\right\}$ NMR data do not suggest interaction of the $\mathrm{C}=\mathrm{C}$ bond with the metal frame, fragment $\mathbf{A}$ would be a potential 7 electron donor to the 55 electron " $\mathrm{Ir}_{4}(\mathrm{CO})_{8}\left(\mathrm{PPh}_{2}\right)$ " fragment, whereas in $\mathbf{B}$ it could donate 6 electrons to the 58 electron " $\operatorname{Ir}_{4}(\mathrm{CO})_{8}\left(\mathrm{PPh}_{2}\right)_{2}$ " fragment. Compound 2 would therefore have 62 (A) or 64 (B) valence electrons and, therefore would exhibit a butterfly or a spiked triangle arrangements of metal atoms according to Wade rules ${ }^{15}$. Similar metal arrangements were previously observed for $\left[\operatorname{Ir}_{4}(\mathrm{CO})_{8}\left(\eta^{1}-\mathrm{COPh}\right)\left(\mu_{4}-\eta^{3}\right.\right.$ $\left.\mathrm{PhPC}(\mathrm{H}) \mathrm{CPh})\left(\mu-\mathrm{PPh}_{2}\right)\right]$ (62 electrons $)^{16}$ and $\left[\operatorname{Ir}_{4}(\mu-\mathrm{H})-\right.$ $\left.(\mathrm{CO})_{9}\left(\mu_{4}-\eta^{3}-\mathrm{Ph}_{2} \mathrm{PCCPh}\right)\left(\mu-\mathrm{PPh}_{2}\right)\right]$ (64 electrons) clusters.

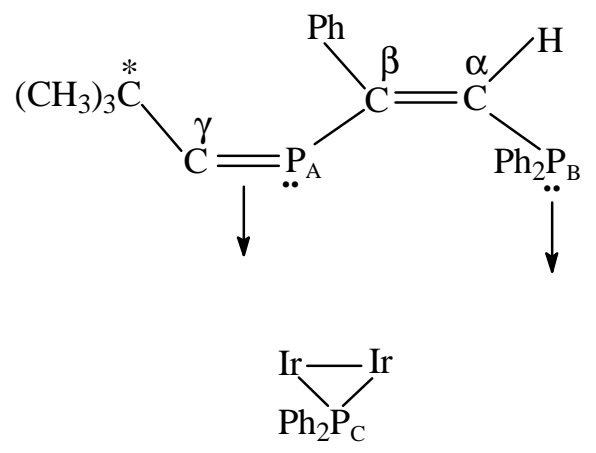

A

\section{Crystal Structure of 2}

The molecular structure of $\mathbf{2}$ in the solid state is shown in Fig. 3, together with the atomic labeling scheme, and confirmed the geometry shown in A. Selected bond distances $(\AA)$ and angles $\left(^{\circ}\right)$ are in Table 1 . The structure consists of a butterfly arrangement of iridium atoms with metal-metal bond mean value of $2.785 \AA$. This arrangement of iridium atoms was previously observed for other 62electron $\mathrm{Ir}_{4}$ clusters for which Ir-Ir bond mean values are comparable e.g. $\left[\mathrm{Ir}_{4}\left(\mathrm{CH}_{3}\right)(\mathrm{CO})_{8}\left(\mu_{4}-\eta^{3}-\mathrm{Ph}_{2} \mathrm{PCCPh}\right)\left(\mu-\mathrm{PPh}_{2}\right)\right]^{17}$, $\left[\begin{array}{ll}2.773 & \AA\end{array}\right], \quad\left[\operatorname{Ir}_{4}(\mathrm{CO})_{8}\left(\mu_{3}-\eta^{3}-\mathrm{Ph}_{2} \mathrm{PC}(\mathrm{H}) \mathrm{CPh}\right)\left(\mu-\mathrm{PPh}_{2}\right)-\right.$ $\left.\left(\mathrm{PCy}_{3}\right)\right]^{18},[2.749 \AA]$ and $\left[\operatorname{Ir}_{4}(\mathrm{CO})_{8}\left(\eta^{1}-\mathrm{COPh}\right)\left(\mu_{4}-\eta^{3}-\right.\right.$ $\left.\mathrm{PhPC}(\mathrm{H}) \mathrm{CPh})\left(\mu-\mathrm{PPh}_{2}\right)\right]^{16},[2.788 \AA]$. Complex 2 possesses seven terminal CO ligands, distributed one on $\operatorname{Ir}(4)$ and two on each remaining Ir atoms, and one bridging carbonyl, which spans asymmetrically the shortest edge of the metal

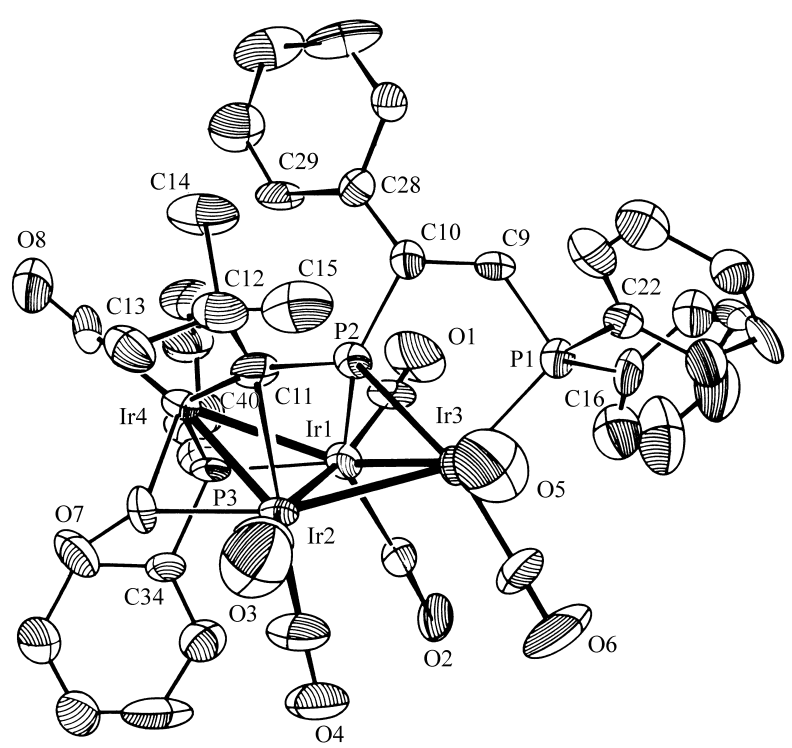

Figure 3. Molecular Structure of $\left[\operatorname{Ir}_{4}(\mu-\mathrm{CO})(\mathrm{CO})_{7}\left(\mu_{4}-\eta^{3}-\mathrm{Ph}_{2} \mathrm{PC}(\mathrm{H})-\right.\right.$ $\left.\left.\mathrm{C}(\mathrm{Ph}) \mathrm{PCBu}^{\mathrm{t}}\right)\left(\mu-\mathrm{PPh}_{2}\right)\right] 2$.

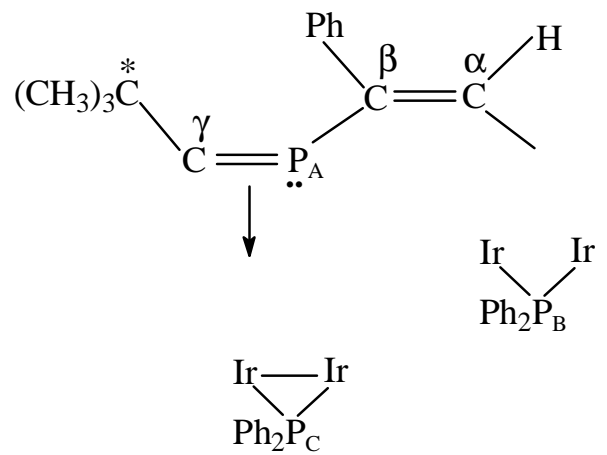

B

Scheme 2. 
Table 1. Selected bond distances $(\AA)$ and angles (deg) for 2.

\begin{tabular}{|c|c|c|c|}
\hline $\operatorname{Ir}(1)-\operatorname{Ir}(2)$ & $2.798(1)$ & $\operatorname{Ir}(1)-\operatorname{Ir}(3)$ & $2.795(1)$ \\
\hline $\operatorname{Ir}(1)-\operatorname{Ir}(4)$ & $2.838(1)$ & $\operatorname{Ir}(2)-\operatorname{Ir}(3)$ & $2.790(1)$ \\
\hline $\operatorname{Ir}(2)-\operatorname{Ir}(4)$ & $2.704(1)$ & $\operatorname{Ir}(1)-P(2)$ & $2.352(5)$ \\
\hline $\operatorname{Ir}(1)-\mathrm{P}(3)$ & $2.390(6)$ & $\operatorname{Ir}(2)-P(2)$ & $2.734(5)$ \\
\hline $\operatorname{Ir}(3)-\mathrm{P}(1)$ & $2.299(6)$ & $\operatorname{Ir}(3)-P(2)$ & $2.277(5)$ \\
\hline $\operatorname{Ir}(4)-\mathrm{P}(3)$ & $2.264(5)$ & $\operatorname{Ir}(1)-C(1)$ & $1.95(2)$ \\
\hline $\operatorname{Ir}(1)-C(2)$ & $1.89(2)$ & $\operatorname{Ir}(2)-C(3)$ & $1.84(2)$ \\
\hline $\operatorname{Ir}(2)-C(4)$ & $1.91(2)$ & $\operatorname{Ir}(2)-C(7)$ & $2.14(2)$ \\
\hline $\operatorname{Ir}(2)-C(11)$ & $2.25(2)$ & $\operatorname{Ir}(3)-C(5)$ & $1.85(3)$ \\
\hline $\operatorname{Ir}(3)-C(6)$ & $1.95(2)$ & $\operatorname{Ir}(4)-C(7)$ & $1.95(2)$ \\
\hline $\operatorname{Ir}(4)-C(8)$ & $1.85(2)$ & $\operatorname{Ir}(4)-C(11)$ & $2.05(2)$ \\
\hline $\mathrm{P}(1)-\mathrm{C}(9)$ & $1.79(2)$ & $\mathrm{P}(1)-\mathrm{C}(16)$ & $1.78(2)$ \\
\hline$P(1)-C(22)$ & $1.78(2)$ & $P(2)-C(10)$ & $1.87(2)$ \\
\hline $\mathrm{P}(2)-\mathrm{C}(11)$ & $1.70(2)$ & $\mathrm{P}(3)-\mathrm{C}(34)$ & $180(2)$ \\
\hline $\mathrm{P}(3)-\mathrm{C}(40)$ & $1.78(2)$ & $C(9)-C(10)$ & $1.32(3)$ \\
\hline $\mathrm{C}(10)-\mathrm{C}(28)$ & $1.44(2)$ & & \\
\hline $\operatorname{Ir}(1)-P(2)-\operatorname{Ir}(2)$ & $66.3(1)$ & $\operatorname{Ir}(1)-\operatorname{Ir}(3)-P(2)$ & $54.1(1)$ \\
\hline $\operatorname{Ir}(1)-\operatorname{Ir}(4)-P(3)$ & $54.5(2)$ & $\operatorname{Ir}(1)-P(3)-\operatorname{Ir}(4)$ & $75.1(2)$ \\
\hline $\operatorname{Ir}(1)-P(2)-\operatorname{Ir}(3)$ & $74.3(2)$ & $\operatorname{Ir}(2)-\operatorname{Ir}(1)-\mathrm{P}(3)$ & $91.0(1)$ \\
\hline $\operatorname{Ir}(2)-\operatorname{Ir}(1)-P(2)$ & $63.4(1)$ & $\operatorname{Ir}(2)-\operatorname{Ir}(3)-\mathrm{P}(2)$ & $64.4(1)$ \\
\hline $\operatorname{Ir}(2)-\operatorname{Ir}(4)-P(3)$ & $96.3(1)$ & $\operatorname{Ir}(3)-\operatorname{Ir}(1)-\mathrm{P}(2)$ & $51.7(1)$ \\
\hline $\operatorname{Ir}(4)-\operatorname{Ir}(1)-P(3)$ & $50.5(1)$ & $\operatorname{Ir}(4)-\operatorname{Ir}(1)-P(2)$ & $65.1(1)$ \\
\hline $\operatorname{Ir}(4)-\operatorname{Ir}(2)-\mathrm{P}(2)$ & $62.5(1)$ & $\mathrm{P}(1)-\operatorname{Ir}(3)-\mathrm{P}(2)$ & $84.4(2)$ \\
\hline $\operatorname{Ir}(1)-\mathrm{C}(1)-\mathrm{O}(1)$ & $176(2)$ & $\operatorname{Ir}(1)-\mathrm{C}(2)-\mathrm{O}(2)$ & $178(2)$ \\
\hline $\operatorname{Ir}(2)-\mathrm{C}(3)-\mathrm{O}(3)$ & $174(3)$ & $\operatorname{Ir}(2)-C(4)-O(4)$ & $172(3)$ \\
\hline $\operatorname{Ir}(3)-\mathrm{C}(5)-\mathrm{O}(5)$ & $177(2)$ & $\operatorname{Ir}(3)-\mathrm{C}(6)-\mathrm{O}(6)$ & $178(3)$ \\
\hline $\operatorname{Ir}(2)-C(7)-O(7)$ & $135(2)$ & $\operatorname{Ir}(2)-C(7)-\operatorname{Ir}(4)$ & $82.8(7)$ \\
\hline $\operatorname{Ir}(4)-\mathrm{C}(7)-\mathrm{O}(7)$ & $142(2)$ & $\operatorname{Ir}(4)-\mathrm{C}(8)-\mathrm{O}(8)$ & $177(2)$ \\
\hline \multicolumn{2}{|c|}{$\operatorname{Ir}(3)-\operatorname{Ir}(1)-\mathrm{P}(3)$} & $150.5(1)$ & \\
\hline \multicolumn{2}{|c|}{$\operatorname{Ir}(1)-\operatorname{Ir}(3)-P(1)$} & $103.6(1)$ & \\
\hline \multicolumn{2}{|c|}{$\operatorname{Ir}(1)-\operatorname{Ir}(4)-C(11)$} & $81.6(6)$ & \\
\hline \multicolumn{2}{|c|}{$\operatorname{Ir}(1)-\operatorname{Ir}(2)-C(11)$} & $79.3(6)$ & \\
\hline \multicolumn{2}{|c|}{$\operatorname{Ir}(1)-P(2)-C(11)$} & $105.4(7)$ & \\
\hline \multicolumn{2}{|c|}{$\operatorname{Ir}(1)-P(2)-C(10)$} & $115.8(5)$ & \\
\hline \multicolumn{2}{|c|}{$\operatorname{Ir}(2)-\operatorname{Ir}(3)-\mathrm{P}(1)$} & $148.7(1)$ & \\
\hline \multicolumn{2}{|c|}{$\operatorname{Ir}(2)-C(11)-P(2)$} & $86.2(8)$ & \\
\hline \multicolumn{2}{|c|}{$\operatorname{Ir}(2)-C(11)-\operatorname{Ir}(4)$} & $77.6(6)$ & \\
\hline \multicolumn{2}{|c|}{$\operatorname{Ir}(3)-P(2)-C(10)$} & $110.5(6)$ & \\
\hline \multicolumn{2}{|c|}{$\operatorname{Ir}(3)-P(2)-C(11)$} & $114.2(6)$ & \\
\hline \multicolumn{2}{|c|}{$\operatorname{Ir}(4)-C(11)-P(2)$} & $97.0(10)$ & \\
\hline \multicolumn{2}{|c|}{$\mathrm{P}(1)-\mathrm{C}(9)-\mathrm{C}(10)$} & $125(2)$ & \\
\hline \multicolumn{2}{|c|}{$P(2)-C(11)-C(12)$} & $129(2)$ & \\
\hline \multicolumn{2}{|c|}{$\mathrm{P}(2)-\operatorname{Ir}(1)-\mathrm{P}(3)$} & $113.6(2)$ & \\
\hline \multicolumn{2}{|c|}{$\mathrm{P}(2)-\mathrm{C}(10)-\mathrm{C}(9)$} & $113.0(14)$ & \\
\hline \multicolumn{2}{|c|}{$P(2)-C(10)-C(28)$} & $121(2)$ & \\
\hline \multicolumn{2}{|c|}{$\mathrm{P}(3)-\operatorname{Ir}(4)-\mathrm{C}(11)$} & $136.0(6)$ & \\
\hline \multicolumn{2}{|c|}{$\operatorname{Ir}(2)-C(11)-C(12)$} & $125.1(14)$ & \\
\hline \multicolumn{2}{|c|}{$\operatorname{Ir}(4)-C(11)-C(12)$} & $127(2)$ & \\
\hline \multicolumn{2}{|c|}{$\mathrm{C}(9)-\mathrm{C}(10)-\mathrm{C}(28)$} & $126(2)$ & \\
\hline \multicolumn{2}{|c|}{$\mathrm{C}(10)-\mathrm{P}(2)-\mathrm{C}(11)$} & $125.3(9)$ & \\
\hline $\mathrm{C}(16$ & $P(1)-C(22)$ & $107.6(10)$ & \\
\hline
\end{tabular}

framework $\operatorname{Ir}(2)-\operatorname{Ir}(4)[2.704(1) \AA, \operatorname{Ir}(4)-\mathrm{C}(7) 1.95(2)$ and $\operatorname{Ir}(2)-\mathrm{C}(7) 2.14(2) \AA]$. The $\operatorname{Ir}(1)-\operatorname{Ir}(4)$ is the longest edge [2.838(1) $\AA$ ] and is spanned by an asymmetric phosphido group $[\operatorname{Ir}(1)-\mathrm{P}(3) 2.390(6)$ and $\operatorname{Ir}(4)-\mathrm{P}(3) \quad 2.265(5) \AA]$ which donates, formally, three electrons to the cluster. The new phosphabutadienyl $\mathrm{Ph}_{2} \mathrm{PC}(\mathrm{H}) \mathrm{C}(\mathrm{Ph}) \mathrm{PCBu}^{\mathrm{t}}$ ligand donates formally seven electrons to the cluster: two from the $\mathrm{P}(1)-\mathrm{C}(9)=\mathrm{C}(10)$ moiety which is interacting with the metal framework via the phosphorus atom lone pair of the $\mathrm{P}(1) \mathrm{Ph}_{2}$ group [ $\left.\operatorname{Ir}(3)-\mathrm{P}(1) 2.299(6) \AA\right]$, five from the 2phosphaalkenyl $\mathrm{P}(2)=\mathrm{C}(11)$ moiety, which is essentially $\mathrm{sp}^{2}\left[\mathrm{P}(2)=\mathrm{C}(11) 1.70(2) \AA, \mathrm{C}(10)-\mathrm{P}(2)=\mathrm{C}(11) 125.3(9)^{\circ}\right.$ and $\left.\mathrm{P}(2)=\mathrm{C}(11)-\mathrm{C}(12) 129(2)^{\circ}\right]$ and interacts with all four iridium atoms via four $\sigma$ bonds [ $\operatorname{Ir}(1)-\mathrm{P}(2)$ 2.352(5), $\operatorname{Ir}(3)$ $\mathrm{P}(2)$ 2.277(5), $\operatorname{Ir}(2)-\mathrm{C}(11)$ 2.25(2) and $\operatorname{Ir}(4)-\mathrm{C}(11)$ 2.05(2) $\AA$ ]. The $\mathrm{P}=\mathrm{C}$ and Ir-P bond distances are comparable with other complexes reported in the literature e.g. $\left[\mathrm{W}(\mathrm{CO})_{5-}\right.$ $\left.\left\{\left(\mathrm{SiMe}_{3}\right)_{2} \mathrm{C}=\mathrm{P}-\mathrm{C}(\mathrm{OEt})=\mathrm{C}(\mathrm{H}) \mathrm{Ph}\right\}\right]^{19}, \quad[\mathrm{P}=\mathrm{C} 1.65(10) \AA]$, $\left[\mathrm{Ru}\left(\mathrm{MeP}=\mathrm{CHBu}^{\dagger}\right) \mathrm{Cl}(\mathrm{I})(\mathrm{CO})\left(\mathrm{PPh}_{3}\right)_{2}\right]^{20},[\mathrm{P}=\mathrm{C} 1.657(8) \AA]$, $\left[\mathrm{TiCp}_{2}\left(\mathrm{Et}_{2} \mathrm{BH}\right)\left(\mathrm{P}=\mathrm{CBu}^{t}\right)\right]^{21},[1.666(2) \AA],\left[\operatorname{Ir}_{4}(\mathrm{CO})_{8}\left(\eta^{1}-\right.\right.$ $\left.\left.\mathrm{COCH}_{3}\right)\left(\mu_{4}-\eta^{3}-\mathrm{Ph}_{2} \mathrm{P}(1) \mathrm{CCPh}\right)\left(\mu-\mathrm{PPh}_{2}\right)\right]^{17}, \quad[\operatorname{Ir}-\mathrm{P}(1)$ 2.307(9) $\mathrm{A}], \quad\left[\mathrm{Ir}_{4}(\mu-\mathrm{H})(\mathrm{CO})_{9}\left(\mu_{4}-\eta^{3}-\mathrm{Ph}_{2} \mathrm{P}(1) \mathrm{CCPh}\right)(\mu-\right.$ $\left.\left.\mathrm{PPh}_{2}\right)\right]^{7}, \quad\left[\begin{array}{lll}\mathrm{Ir}-\mathrm{P}(1) & 2.373(9) & \AA\end{array}\right]$, $\left[\mathrm{Ir}_{4}(\mathrm{CO})_{8}\left(\mu_{3}-\eta^{3}-\mathrm{Ph}_{2} \mathrm{P}(1) \mathrm{C}(\mathrm{H}) \mathrm{CPh}\right)\left(\mu-\mathrm{PPh}_{2}\right)(\mathrm{PCy})\right]^{18},[\mathrm{Ir}-$ $\mathrm{P}(1) 2.270 \AA$ ] . A formal electron count in 2 results in 19 and 17 electrons on $\operatorname{Ir}(2)$ and $\operatorname{Ir}(4)$, respectively, and 18 electrons on the other two metal atoms. This has been previously observed for other $\mathrm{Ir}_{4}$ clusters such as $\left[\mathrm{Ir}_{4}(\mathrm{CO})_{8}\left(\eta^{1}-\mathrm{COCH}_{3}\right)-\left(\mu_{4}-\eta^{3}-\mathrm{Ph}_{2} \mathrm{PCCPh}\right)\left(\mu-\mathrm{PPh}_{2}\right)\right]$,

$\left[\mathrm{Ir}_{4}(\mathrm{CO})_{8}\left(\eta^{1}-\mathrm{CH}_{3}\right)\left(\mu_{4}-\eta^{3}-\mathrm{Ph}_{2} \mathrm{PCCPh}\right)\left(\mu-\mathrm{PPh}_{2}\right)\right]$ and $\left[\mathrm{Ir}_{4}(\mathrm{CO})_{8}\left(\mu_{3}-\eta^{3}-\mathrm{Ph}_{2} \mathrm{P} \mathrm{C}(\mathrm{H}) \mathrm{CPh}\right)\left(\mu-\mathrm{PPh}_{2}\right)\left(\mathrm{PCy}_{3}\right)\right]$.

Although the X-ray diffraction study has confirmed structure $\mathbf{A}$, proposed in Scheme 2 for the novel chain, it is impossible to be sure that $\mathrm{P}-\mathrm{C}$ bond cleavage was not involved in the process, considering the analogous transformation of $\left[\mathrm{Ru}_{3}(\mu-\mathrm{H})(\mathrm{CO})_{8}\left(\mu_{3}-\eta^{2}-\mathrm{CCBu}^{t}\right)\left(\mathrm{Ph}_{2} \mathrm{PC} \equiv\right.\right.$ $\mathrm{CPh})]$ into $\left[\mathrm{Ru}_{3}(\mathrm{CO})_{8}\left\{\mu_{3}-\eta^{4}-\mathrm{Ph}{ }_{2} \mathrm{PC}(\mathrm{Ph}) \mathrm{C}(\mathrm{H}) \mathrm{CC}\left(\mathrm{Bu}^{\mathrm{t}}\right)\right\}\right]^{22}$. In this case, the alkyne-alkyne condensation and migration of the hydride ligand resulted in a new organic chain, $\mathrm{Ph}_{2} \mathrm{PC}(\mathrm{Ph}) \mathrm{C}(\mathrm{H}) \mathrm{CC}\left(\mathrm{Bu}^{t}\right)$. It was suggested that a $\mathrm{P}-\mathrm{C} \alpha$ bond cleavage had initially occurred, with formation of a $\mu-\mathrm{PPh}_{2}$ ligand, and after the condensation, insertion of the new carbon chain, " $\mathrm{C}(\mathrm{Ph}) \mathrm{C}(\mathrm{H}) \mathrm{CC}\left(\mathrm{Bu}^{t}\right)$ ", into the $\mathrm{Ru}-\mathrm{PPh}_{2}$ occurred leading to the observed $\mathrm{P}-\mathrm{C} \beta(\mathrm{Ph})$; all these proposed steps had been previously observed.

No information regarding the detailed mechanism of the formation of compound $\mathbf{2}$ is available, but one can speculate the following steps: (i) CO loss and interaction of the acetylene moiety with an electron poor Ir center with a Ir-Ir bond cleavage, (ii) hydride migration to the $\mathrm{C} \alpha$ of the $\mathrm{Ph}_{2} \mathrm{PCCPh}$ ligand, and (iii) nucleophilic attack of the 


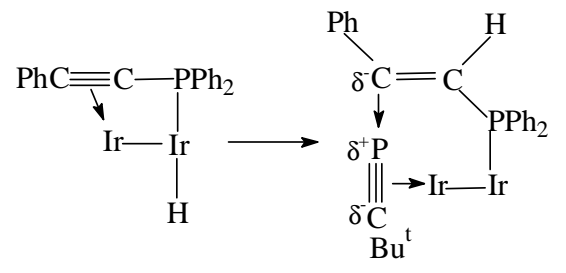

$\mathrm{C} \beta$ at the $\delta^{+} \mathrm{P}$ of the $\mathrm{PCBu}{ }^{\mathrm{t}}$ ligand with formation of the 2-phosphabutadienylphosphine observed experimentally.

\section{Experimental}

\section{General procedures}

All manipulations and reactions were performed under an atmosphere of argon, unless otherwise specified, using standard Schlenk techniques. $\mathrm{CH}_{2} \mathrm{Cl}_{2}$ was dried over $\mathrm{CaH}_{2}$, hexane and thf over sodium wire. Solvents were freshly distilled under $\mathrm{N}_{2}$ from $\mathrm{Na} / \mathrm{K}$ alloy (hexane and thf) or from $\mathrm{CaH}_{2}\left(\mathrm{CH}_{2} \mathrm{Cl}_{2}\right)$ prior to use. $\mathrm{P} \equiv \mathrm{CBu}^{\mathrm{t}},{ }^{3}\left[\mathrm{Ir}_{4}(\mu-\mathrm{H})(\mathrm{CO})_{9}\right.$ $\left.\left(\mathrm{Ph}_{2} \mathrm{PC} \equiv \mathrm{CPh}\right)\left(\mu-\mathrm{PPh}_{2}\right)\right]^{7}, \mathbf{1}$ and $\left[\mathrm{Ir}_{4}(\mathrm{CO})_{10}\left(\mathrm{Ph}_{2} \mathrm{PC} \equiv \mathrm{CPh}\right)\right.$ $\left.\left(\mathrm{PPh}_{2} \mathrm{H}\right)\right]^{7}, \mathbf{3}$ were prepared by literature methods.

Preparative TLC was carried out in air by using $c a .2$ $\mathrm{mm}$ thickness glass-backed silica plates $(20 \times 20 \mathrm{~cm})$ prepared from silica gel type $\mathrm{GF}_{254}$ (Fluka) and $\mathrm{CH}_{2} \mathrm{Cl}_{2}$ hexane (3:7) as eluent and the compounds were extracted from silica with $\mathrm{CH}_{2} \mathrm{Cl}_{2}$.

IR spectra were obtained on a Bomen MB series IR instrument scanning between 2200 and $1600 \mathrm{~cm}^{-1}$, using $\mathrm{CaF}_{2}$ cells. Microanalyses were performed at the Instituto de Química, Unicamp, Brazil. Fast atom bombardment mass spectra (FAB MS) were obtained on a Kratos MS50, operating at $8 \mathrm{keV}$. Xenon was used as the source of fast atoms. 3-Nitrobenzylalcohol, purchased from Aldrich, and distilled under vacuo, was used as a matrix. $\mathrm{CH}_{2} \mathrm{Cl}_{2}$ was used as solvent. All $\mathrm{m} / \mathrm{z}$ values are referred to ${ }^{193} \mathrm{Ir}$ and were obtained at the University Chemical Laboratories, University of Cambridge, UK. ${ }^{1} \mathrm{H},{ }^{13} \mathrm{C}$ and ${ }^{13} \mathrm{P}$-NMR studies were carried out using $\mathrm{CDCl}_{3}$ solutions and a Bruker AMX 500 spectrometer. Standard pulse sequences were used for the NMR experiments ${ }^{23}$. Chemical shifts are given in ppm using deuterated solvents as lock and reference $\left({ }^{1} \mathrm{H}\right.$ and ${ }^{13} \mathrm{C}$, $\mathrm{SiMe}_{4} ;{ }^{31} \mathrm{P} 85 \% \mathrm{H}_{3} \mathrm{PO}_{4}$, external) and coupling constants $(J)$ are given in $\mathrm{Hz}$.

\section{Preparation of $\left[\mathrm{Ir}_{4}(\mathrm{CO})_{8}\left\{\mu_{4}-\eta^{3}-P h_{2} P C(H) C(P h) P C B u^{\mathrm{t}}\right\}\right.$ $\left.\left(\mu-P P h_{2}\right)\right] 2$ \\ Method 1}

An orange solution of $\left[\operatorname{Ir}_{4}(\mu-\mathrm{H})(\mathrm{CO}){ }_{9}\left(\mathrm{Ph}_{2} \mathrm{PC} \equiv \mathrm{CPh}\right)(\mu\right.$ $\left.\left.\mathrm{PPh}_{2}\right)\right] 1(100 \mathrm{mg}, 0.08 \mathrm{mmol})$ and $\mathrm{P} \equiv \mathrm{CBu}^{\mathrm{t}}(8 \mu \mathrm{L}, 0.08$ mmol) in $\mathrm{CH}_{2} \mathrm{Cl}_{2}(10 \mathrm{~mL})$ was heated at $35^{\circ} \mathrm{C}$ for $4 \mathrm{~h}$, after which time a color change from orange to dark brown was observed. The solution was concentrated under vacuo to about $1 \mathrm{~mL}$ and the mixture purified by TLC to afford
$\left[\operatorname{Ir}_{4}(\mathrm{CO})_{8}\left\{\mu_{4}-\eta^{3}-\mathrm{Ph}_{2} \mathrm{PC}(\mathrm{H}) \mathrm{C}(\mathrm{Ph}) \mathrm{PCBu}^{\mathrm{t}}\right\}\left(\mu-\mathrm{PPh}_{2}\right)\right] \mathbf{2}(60$ $\mathrm{mg}, 48 \%, \mathrm{R}_{\mathrm{f}} 0.30$, brown), $\left[\operatorname{Ir}_{4}(\mathrm{CO})_{8}\left\{\mu_{3}-\eta^{2}-\mathrm{HCCPh}\right)(\mu-\right.$ $\left.\left.\mathrm{PPh}_{2}\right)_{2}\right] 4\left(15 \mathrm{mg}, 12 \%, \mathrm{R}_{\mathrm{f}} 0.55\right.$, orange) and starting material 1 ( $15 \mathrm{mg}, 15 \%, \mathrm{R}_{\mathrm{f}} 0.41$, orange).

\section{Method 2}

To a yellow solution of $\left[\operatorname{Ir}_{4}(\mathrm{CO})_{10}\left(\mathrm{Ph}_{2} \mathrm{PC} \equiv \mathrm{CPh}\right)\right.$ $\left.\left(\mathrm{PPh}_{2} \mathrm{H}\right)\right] 3$ (53 mg, $\left.0.035 \mathrm{mmol}\right)$ in thf $(10 \mathrm{~mL}) \mathrm{P} \equiv \mathrm{CBu}^{\mathrm{t}}(7$ $\mu \mathrm{L}, 0.07 \mathrm{mmol}$ ) was added and the reaction mixture was heated at $40{ }^{\circ} \mathrm{C}$ for $48 \mathrm{~h}$. The resulting brown solution was concentrated under vacuo to about $1 \mathrm{~mL}$. Separation of the mixture by TLC afforded $\left[\mathrm{Ir}_{4}(\mathrm{CO})_{8}\left\{\mu_{4}-\eta^{3}-\mathrm{Ph}_{2} \mathrm{PC}(\mathrm{H}) \mathrm{C}(\mathrm{Ph})\right.\right.$ $\left.\left.\mathrm{PCBu}^{\mathrm{t}}\right\}\left(\mu-\mathrm{PPh}_{2}\right)\right] 2\left(5 \mathrm{mg}, 10 \%, \mathrm{R}_{\mathrm{f}} 0.58\right.$, brown $),\left[\mathrm{Ir}_{4}(\mathrm{CO})_{8}\right.$ $\left.\left\{\mu_{3}-\eta^{2}-\mathrm{HCCPh}\right)\left(\mu-\mathrm{PPh}_{2}\right)_{2}\right] 4\left(2 \mathrm{mg}, 4 \%, \mathrm{R}_{\mathrm{f}} 0.67\right.$, orange), and unreacted $\mathbf{3}\left(27 \mathrm{mg}, 50 \%, \mathrm{R}_{\mathrm{f}} 0.62\right.$, yellow), along with some decomposition products (base line on the TLC plates).

\section{Reaction of $\left[\operatorname{Ir}_{4}(\mathrm{CO})_{8}\left\{\mu_{3}-\eta^{2}-H C C P h\right)\left(\mu-P P h_{2}\right)_{2}\right] 4$ with $P \equiv C B u^{\mathrm{t}}$}

(a) To a solution of $\left[\operatorname{Ir}_{4}(\mathrm{CO})_{8}\left\{\mu_{3}-\eta^{2}-\mathrm{HCCPh}\right)-\right.$ $\left.\left(\mu-\mathrm{PPh}_{2}\right)_{2}\right] 4(27 \mathrm{mg}, 0.018 \mathrm{mmol})$ in $\mathrm{CH}_{2} \mathrm{Cl}_{2}(10 \mathrm{~mL})$ was added $\mathrm{P} \equiv \mathrm{CBu}^{\mathrm{t}}(5.2 \mu \mathrm{L}, 0.046 \mathrm{mmol})$ and the reaction mixture heated at $35^{\circ} \mathrm{C}$ for $5 \mathrm{~h}$. After $\mathrm{ca} .10 \mathrm{~min}$ the color of the solution slowly began to change from orange to brown and after $5 \mathrm{~h}$ the solution was dark brown. Purification by preparative TLC afforded unreacted starting material 4 along with decomposition on the base line of the TLC plates.

(b) A solution of 4 (70 mg, $0.047 \mathrm{mmol})$ and $\mathrm{P} \equiv \mathrm{CBu}^{\mathrm{t}}$ $(10 \mu \mathrm{L}, 0.095 \mathrm{mmol})$ in benzene $(20 \mathrm{~mL})$ in a closed Schlenk fitted with Young tap, was heated under reflux for $4 \mathrm{~h}$, a slowly color change from orange to dark brown was observed. The solvent was removed under reduced pressure and separation by preparative TLC afforded the starting material 4, along with decomposition products on the base line of the TLC plates.

\section{Characterization of 2}

Anal. Calcd. for $\mathrm{C}_{45} \mathrm{H}_{35} \mathrm{O}_{8} \mathrm{P}_{3} \mathrm{Ir}_{4}: \mathrm{C}, 34.5 ; \mathrm{H}, 2$.2. Found: C, 34.7; H, 1.9\%. IR (hexane, $v_{\mathrm{CO}}$ ): $2068 \mathrm{w}, 2058 \mathrm{w}$, 2030vs, 2014w (sh), 2006s, 1985w, 1956s, $1836 \mathrm{~m} \mathrm{~cm}^{-1}$. FAB MS: $m / z, 1568(M)^{+}, 1540(M-\mathrm{CO})^{+}, 1512(M-2 \mathrm{CO})^{+}$, $1484(M-3 \mathrm{CO})^{+}, 1456(M-4 \mathrm{CO})^{+}, 1428(M-5 \mathrm{CO})^{+}, 1400$ $(M-6 \mathrm{CO})^{+}, 1372(M-7 \mathrm{CO})^{+}$and $1344(M-8 \mathrm{CO})^{+} .{ }^{1} \mathrm{H}$ NMR $\left(500 \mathrm{MHz}, \mathrm{CDCl}_{3}, 25^{\circ} \mathrm{C}\right): \delta 1.1\left(\mathrm{~s}, 9 \mathrm{H}, \mathrm{C}\left(\mathrm{CH}_{3}\right)_{3}\right), 5.4(\mathrm{dd}$, $1 \mathrm{H}, J_{\mathrm{H}-\mathrm{P}} 55$ and $\left.13 \mathrm{~Hz}\right), 6.9-7.5\left(\mathrm{~m}, 25 \mathrm{H}, \mathrm{C}_{6} H_{5}\right) .{ }^{13} \mathrm{C}\left\{{ }^{1} \mathrm{H}\right\}$ NMR $\left(125.721 \mathrm{MHz}, \mathrm{CDCl}_{3}, 25^{\circ} \mathrm{C}\right): \delta 191.2\left(\mathrm{~d}, J_{\mathrm{C}-\mathrm{P}} 6 \mathrm{~Hz}\right.$, $C O), 183.3\left(\mathrm{~d}, J_{\mathrm{C}-\mathrm{P}} 73 \mathrm{~Hz}, C \mathrm{O}\right), 175.5$ (t, $J_{\mathrm{C}-\mathrm{P}} 35 \mathrm{~Hz}, C \mathrm{O}$ ), $173.8\left(\mathrm{~d}, J_{\mathrm{C}-\mathrm{P}} 49 \mathrm{~Hz}, C \mathrm{CO}\right), 170.4$ (s, $\left.C O\right), 168.0$ (d, $J_{\mathrm{C}-\mathrm{P}} 25$ $\mathrm{Hz}, C \mathrm{O}), 165.8$ (d, $\left.J_{\mathrm{C}-\mathrm{P}} 111 \mathrm{~Hz}, C \mathrm{CO}\right), 161.8(\mathrm{br}, C \mathrm{CO}), 141.7$ (d, $\left.J_{\mathrm{C}-\mathrm{P}} 33 \mathrm{~Hz}, C_{\text {quat. }}, \mathrm{Ph}\right), 138.4$ (d, $\left.J_{\mathrm{C}-\mathrm{P}} 30 \mathrm{~Hz}, C_{\text {quat. }}, \mathrm{Ph}\right)$, 
$136.0\left(\mathrm{~d}, J_{\mathrm{C}-\mathrm{P}} 57 \mathrm{~Hz}, C_{\text {quat. }}, \mathrm{Ph}\right), 134.8$ (dd, $J_{\mathrm{C}-\mathrm{P}} 21$ and 8 $\left.\mathrm{Hz}, C_{\text {quat. }}, \mathrm{Ph}\right), 133.7$ (d, $\left.J_{\mathrm{C}-\mathrm{P}} 13 \mathrm{~Hz}, C \mathrm{H}, \mathrm{Ph}\right), 132.6$ (d, $J_{\mathrm{C}-\mathrm{P}}$ $11 \mathrm{~Hz}, C H, \mathrm{Ph}$ ), 132.1 (d, JC-P $13 \mathrm{~Hz}, C H, \mathrm{Ph}$ ), 131.7 (s, $\mathrm{CH}, \mathrm{Ph}$ ), 130.5 (s, $\mathrm{CH}, \mathrm{Ph}), 130.1$ (s, $\left.C_{\text {quat. }}, \mathrm{Ph}\right), 130.0$ (s, $C H, P h), 129.6$ (t, $\left.J_{\mathrm{C}-\mathrm{P}} 8, C \mathrm{H}, \mathrm{Ph}\right), 129.1$ (d, $J_{\mathrm{C}-\mathrm{P}} 11 \mathrm{~Hz}, C H$, $\mathrm{Ph}), 128.6\left(\mathrm{~d}, J_{\mathrm{C}-\mathrm{P}} 12 \mathrm{~Hz}, C \mathrm{H}, \mathrm{Ph}\right), 128.3$ (t, $J_{\mathrm{C}-\mathrm{P}} 11 \mathrm{~Hz}, C \mathrm{H}$, $\mathrm{Ph}$ ), 126.0 (dd, $J_{\mathrm{C}-\mathrm{P}} 57$ and $\left.35 \mathrm{~Hz}, C \mathrm{H}\right), 54.2$ (dd, $J_{\mathrm{C}-\mathrm{P}} 37$ and $\left.28 \mathrm{~Hz}, C_{\text {quat. }}\right), 38.5$ (s, $\left.C_{\text {quat. }}\right), 36.6$ (d, $\left.J_{\mathrm{C}-\mathrm{P}} 8 \mathrm{~Hz}, \mathrm{CCH}_{3}\right)$, 29.6 (s, $\left.C_{\text {quat. }}\right) .{ }^{31} \mathrm{P}\left\{{ }^{1} \mathrm{H}\right\} \mathrm{NMR}\left(202.404 \mathrm{MHz}, \mathrm{CDCl}_{3}\right.$, $\left.25^{\circ} \mathrm{C}\right): \delta 16.1\left(\mathrm{P}_{1}, \mathrm{t}, J_{\mathrm{P}-\mathrm{P}} 5 \mathrm{~Hz}\right), 28.0\left(\mathrm{P}_{2}, \mathrm{t}, J_{\mathrm{P}-\mathrm{P}} 5 \mathrm{~Hz}\right), 116.5$ $\left(\mathrm{P}_{3}, \mathrm{t}, J_{\mathrm{P}-\mathrm{P}} 5 \mathrm{~Hz}\right)$.

\section{$X$-ray structure determination of 2}

$\mathrm{X}$-ray quality crystals were grown by slow evaporation of a very concentrated $\mathrm{CHCl}_{3}$ solution of 2 . Data were collected at $293 \mathrm{~K}$ on an Enraf-Nonius CAD4 diffractome-

Table 2. Crystal data and details of measurements for compound 2.

\begin{tabular}{|c|c|}
\hline Empirical formula & $\mathrm{C}_{45} \mathrm{H}_{35} \mathrm{Ir}_{4} \mathrm{O}_{8} \mathrm{P}_{3} \cdot \mathrm{CHCl}_{3}$ \\
\hline Formula weight & 1684.8 \\
\hline Crystal system & Monoclinic \\
\hline Space group & $\mathrm{C} 2 / \mathrm{c}(\mathrm{N} .15)$ \\
\hline a & $41.913(8)(\AA)$ \\
\hline $\mathrm{b}$ & 12.747 (4) (§) \\
\hline $\mathrm{c}$ & $18.522(5)(\AA)$ \\
\hline$\beta$ & $95.17(\mathrm{deg})$ \\
\hline Volume & $9855 \AA^{3}$ \\
\hline $\mathrm{Z}$ & 8 \\
\hline Density (calculated) & $2.27\left(\mathrm{Mg} \mathrm{m}^{-3}\right)$ \\
\hline Absorption coefficient & $110.8\left(\mathrm{~cm}^{-1}\right)$ \\
\hline $\mathrm{F}(000)$ & 6240 \\
\hline Crystal size & $0.4 \times 0.2 \times 0.1(\mathrm{~mm})$ \\
\hline Wavelength & $0.71073(\AA)$ \\
\hline Temperature & 293(2) K \\
\hline$\theta$ range & 2 to 25 (deg) \\
\hline Index ranges & $0 \leq \mathrm{h} \leq 49,0 \leq \mathrm{k} \leq 15,-22 \leq 1 \leq 21$ \\
\hline Reflections collected & 9198 \\
\hline Independent reflections & $8654\left[\mathrm{R}_{\mathrm{int}}=0.04\right]$ \\
\hline Reflections with I > $2 \sigma(\mathrm{I})$ & 5449 \\
\hline Structure solution & Direct methods \\
\hline Refinement method & Full-matrix on all $\mathrm{F}^{2}$ \\
\hline Data/restraints/parameters & $8641 / 0 / 577$ \\
\hline Goodness-of-fit on $\mathrm{F}^{2}$ & 1.072 \\
\hline Final $R$ indices $[\mathrm{I}>2 \sigma(\mathrm{I})]$ & $\mathrm{R}_{1}=0.064, w \mathrm{R}_{2}=0.126$ \\
\hline $\mathrm{R}$ indices (all data) & $\mathrm{R}_{1}=0.121, \mathrm{wR}_{2}=0.158$ \\
\hline Largest diff. peak and hole & 1.62 and -2.34 e. $\AA^{-3}$ \\
\hline Abs. correction from psi scans & $\mathrm{T}_{\max }=1.00, \mathrm{~T}_{\min }=0.46$ \\
\hline Maximum shift/e.s.d & 0.002 \\
\hline
\end{tabular}

ter. Crystal and refinement details are given in Table 2. Non-H atoms were located by heavy atom methods and the structure refined using SHELXS-86 ${ }^{24}$ and refined on $\mathrm{F}^{2}$ with all reflections using SHELXS-93 ${ }^{24}$. Hydrogen atoms were included in rigid mode.

Atomic coordinates, thermal parameters and a full list of bond lengths and angles have been deposited at the Cambridge Crystallographic Data Centre.

\section{Acknowledgements}

We acknowledge financial support from the Commission of European Communities, Conselho Nacional de Desenvolvimento Científico e Tecnológico - CNPq (M.H.A, M.D.V) and Fundação de Amparo à Pesquisa do Estado de São Paulo - FAPESP (M.H.A). We thank Dr. Anthony G. Avent for all his help with the NMR experiments.

\section{References}

1. Sappa, E.; Tiripicchio, A.; Braunstein, P. Chem. Rev. 1983, 83, 203; Shapley, J.R.; McAteer, C.H.; Churchill, M.R.; Biondi, L.V. Organometallics 1984, 3, 1595; Riaz, V.; Curtis, M.D.; Rheingold, A.; Haggerty, B.S. Organometallics 1990, 9, 2647; Matsuzaka, H.; Mizobe, Y.; Nishio, M.; Hidai, M. J. Chem. Soc., Chem. Commun. 1991, 1011.

2. Pereira, R.M.S. Ph.D. Thesis, Universidade Estadual de Campinas, Brazil, 1996.

3. Nixon, J.F. Chem. Rev. 1988, 88, 1327; Chem. Ind. 1993, 404; Coord. Chem. Rev. 1995, 145, 201; Chem. Soc. Rev. 1995, 319; Dillon, K.B.; Mathey, F.; Nixon, J.F. Phosphorus: The Carbon Copy 1998, Ed. John Wiley.

4. Imhof, W.; Huttner, G. J. Organomet. Chem. 1993, 447, 31.

5. Binger, P.; Milczarek, R.; Mynott, R.; Regitz, M. J. Organomet. Chem. 1987, 323, C35; Regitz, M. In Multiple Bond and Low Coordination in Phosphorus Chemistry, Ed. Regitz, M.; Scherer, O.J., Georg Thieme Verlag, Stuttgart, 1990, Chapter 2.

6. Appel, R. In Multiple Bonds and Low Coordination in Phosphorus Chemistry, Ed. Regitz, M.; Scherer, O.J., Georg Thieme Verlag, Stuttgart, 1990, Chapter 2.

7.Benvenutti. M.H.A.; Vargas, M.D.; Braga, D.; Grepioni, F.; Mann, B.E.; Naylor, S. Organometallics 1993, 12, 2947 and references therein.

8.Sappa, E.; Pasquinelli, G.; Tiripicchio, A.; Tiripicchio-Camellini, M. J. Chem. Soc., Soc., Dalton Trans. 1989, 601 and references therein.

9. Chi, Y.; Hwang, D.-K.; Chen, S.-F.; Liu, L.-K. J. Chem. Soc., Chem. Commun. 1989, 1540; Chi, Y.; Huttner, G.; Imhof, W. J. Organomet. Chem. 1990, $384,93$. 
10. Benvenutti, M.H.A.; Hitchcock, P.B.; Nixon, J.F.; Vargas, M.D. J. Chem. Soc., Chem. Commun. 1994, 1869.

11. Araujo, M.H. Ph.D. Thesis, Universidade Estadual de Campinas, Brazil, 1995.

12. Verkade, J.G.; Mosbo, J.A. in Phosphorus-31 NMR Spectroscopy in Stereochemical Analysis, Ed. Verkade, J.G. and Quin, L.D., 1987, VHC, Chapter 13.

13. Doherty, S.; Corrigan, J.F.; Carty, A.J.; Sappa, E. Adv. Organomet. Chem. 37, 39.

14. Mann, B.E.; Pickup, B.T.; Smith, A.K. J. Chem. Soc., Dalton Trans. 1989, 889.

15. Mingos, D.M.P.; May, A.S. In Structural and Bonding Aspects of Metal Cluster Chemistry, Shriver, D.F.; Kaesz, H.D.; Adams, R.D., eds., VHC, 1990, 16, 4833.

16. Pereira, R.M.S.; Fijiwara, F.Y.; Vargas, M.D.; Braga, D.; Grepioni, F. Organometallics 1997, 16, 4833.

17. Vargas, M.D.; Pereira, R.M.S.; Braga, D.; Grepioni, F. J. Chem. Soc., Chem. Commun. 1993, 1008.

18. Benvenutti. M.H.A.; Vargas, M.D.; Braga, D.; Grepioni, F.; Parisini, E.; Mann, B.E. Organometallics 1993, 12, 2955, and references therein.
19. Hobbold, M.; Streubel, R.; Benvenutti, M.H.A.; Hitchcock, P.B.; Nixon, J.F. Organometallics 1997, 16, 3726.

20. Bedford, R.B.; Hill, A.F.; Jones, C.; White, A.J.P.; Wilton-Ely, J.D.E.T. J. Chem. Soc., Dalton Trans. 1997, 139.

21. Binger, P.; Sandmeyer, F.; Krüger, C.; Jörg, K.; Goddard, R.; Erker, G. Angew. Chem. Int. Ed. Engl. 1994, 33, 197.

22. Sappa, E.; Pasquinelli, G.; Tiripichio, A.; Camellini, M.T. J. Chem. Soc., Dalton Trans. 1989, 601 and references therein.

23. Mann, B.E. Adv. Organomet. Chem. 1988, 28, 397 and references therein.

24. Enraf-Nonius, CAD-4 Software. Version 5.0, 1989. Enraf-Nonius, The Netherlands. Sheldrick, G.M., 1985, SHELXS-86. Program for the Solution of Crystal Structures. University of Gottingen Germany. Sheldrick, G.M. (1993) SHELXL-93. Program for Crystal Structure Refinement. University of Gottingen, Germany. Watkin, D.J. and Pearce, L.J., 1993 CAMERON. An Interactive Graphics Editor. University of Oxford, England.

FAPESP helped in meeting the publication costs of this article 